\title{
触 New Disease Reports \\ First report of Nerine latent virus in Haemanthus albiflos in the UK
}

W.A. Monger and R.J. Eden

Science and Advice for Scottish Agriculture (SASA), Roddinglaw Road, Edinburgh, EH12 9FJ, United Kingdom

*E-mail: wendy.monger@sasa.gsi.gov.uk

Received: 12 Nov 2018. Published: 22 Jan 2019.

Haemanthus albiflos is a flowering plant native to South Africa and Namibia. A member of the family Amaryllidaceae, it is an evergreen bulbous perennial with unusual flowers that give it the common name of paintbrush. Tolerance for indirect sunlight and neglect has made this a popular houseplant in countries where it would not survive the winter climate. One such house plant bought at a UK nursery in the late 1990's, was later recognised as showing mild streaking symptoms consistent with a virus infection (Fig. 1). The authors can find no record of viruses associated with Haemanthus albiflos but the related plant Haemanthus multiflorus (blood lily) recently removed from the Haemanthus genus and renamed Scadoxus multiflorus, is a host for Nerine latent virus (NeLV) (Chen et al., 2016). From accessions on the NCBI database blood lily is also recorded as a host plant for Cucumber mosaic virus (CMV) and Tomato spotted wilt virus (TSWV).

The haemanthus plant was investigated using immuno-strips (Agdia) to detect CMV, Impatiens necrotic spot virus, Iris yellow spot virus and TSWV but no antibody reactions occurred. This was followed by total RNA extraction from leaves (Plant RNeasy kit, Qiagen) and RT-PCR with generic primers that amplify viruses from the Carlavirus (Nie et al., 2008) and Potexvirus genera (van der Vlugt \& Berendsen, 2002) and the Potyviridae family (Gibbs \& Mackenzie, 1997). The testing indicated a positive result with the carlavirus primer set Car-F2b and oligo-dT. The sequenced PCR product when compared to the NCBI database, indicated a close match with Nerine latent virus (NeLV), also known as Narcissus symptomless virus. To further characterise this isolate, the complete coat protein (CP) was amplified (Genbank Accession No. MK085064) using specific primers either side of the $\mathrm{CP}$ region (NeLV6946F 5'-AGAGTTTAGTGTCCTCTTAGGTTTA-3', NeLV8018R 5'-AAGGAGCCACACTTGATTGTCTT-3'). Sequence alignments, with available NeLV CP sequences (NCBI database), showed that the virus isolates shared high identity with each other, $95-98 \%$ at the nucleotide level. The highest identity of $98 \%$ was with JX524884 from narcissus (Taiwan) and HM119498 from nerine (Netherlands). The alignments revealed the haemanthus isolate had three nucleotides (one amino acid) less than other NeLV isolates and this deletion was located near the five prime end of the CP. The phylogenetic relationship of the NeLV CPs from different host plants and countries of origin are shown in Figure 2.

NeLV is reported as symptomless in the blood lily plant (Chen et al., 2016) and previously in the host species of Nerine bowdenii and Hippeastrum hybridum (Brunt et al., 1996) but mosaic symptoms have been reported in Crinum plants (Jordan et al., 2018). The symptoms produced by NeLV on indicator plants have been recorded (Brunt et al., 1996): local chlorotic

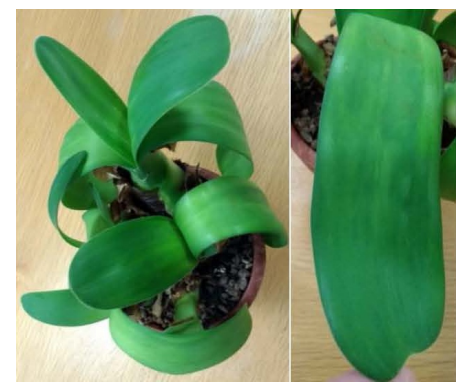

Figure 1
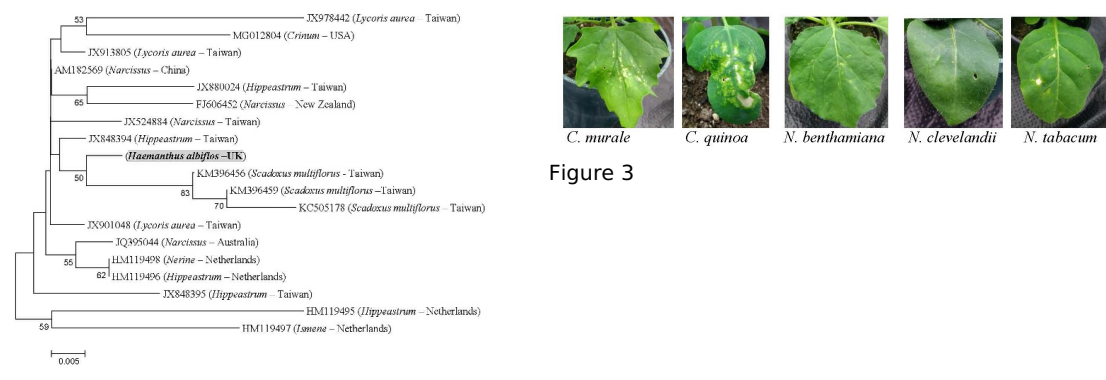

Figure 3

Figure 2

To cite this report: Monger WA, Eden RJ, 2019. First report of Nerine latent virus in Haemanthus albiflos in the UK. New Disease Reports 39, 3. http://dx.doi.org/10.5197/j.2044-0588.2019.039.003

(c) 2019 The Authors This report was published on-line at www.ndrs.org.uk where high quality versions of the figures can be found. 